\title{
Comparison of Cytosolic and Mitochondrial Hepatic Enzyme Alterations in Reye's Syndrome
}

\author{
ROBERT A. MITCHELL, ${ }^{(41) !}$ MICHAL L. RAM, EDGARDO L. ARCINUE, AND CHUNG HO CHANG \\ Departments of Biochemistry, Pediatrics, and Pathology. Wayne State University School of Medicine, and the \\ Children's Hospital of Michigan, Detroit, Michigan, USA
}

\begin{abstract}
Summary
The activities of nine enzymes in liver specimens obtained from four children who had died from Reye's syndrome were compared to the corresponding activities of a control group of four children who had died from unrelated causes. At the $95 \%$ significance level, the alterations could be classified into three groups. Five activities |lactate dehydrogenase, alanine aminotransferase, glucose 6-phosphatase, cytochrome oxidase, and malate dehydrogenase (mitochondrial plus cytosolic)| showed no change. Three enzymes |glutamate dehydrogenase, isocitrate dehydrogenase (NADP), and monoamine oxidase| were decreased. One activity (glucose 6phosphate dehydrogenase) was increased.

The malate dehydrogenase isozymes were resolved by electrophoresis, and the two bands were stained and measured. The ratio of cytosolic:mitochondrial enzyme was significantly greater in Reye's syndrome than in the control group. These results lend further support to the view that in Reye's syndrome the impairment of hepatic function is largely confined to the mitochondria. The lowered activity of monoamine oxidase means that the abnormalities extend to the outer mitochondrial membrane.

Imbalances of the cytosolic:mitochondrial enzyme activities were evaluated in needle biopsy specimens from four other children under conditions where the neurologic abnormalities were less severe. Two patients had elevated ratios of both glutamate:lactate dehydrogenase and cytosolic:mitochondrial malate dehydrogenase activities, and a third had only an abnormal malate dehydrogenase ratio. In contrast to these Reye's syndrome patients, a fourth case admitted with a provisional diagnosis of Reye's syndrome showed no abnormality in either ratio in stage IV coma.
\end{abstract}

\section{Speculation}

The decreased activities of hepatic mitochondrial enzymes in Reye's syndrome may reflect a generalized decrease in the steadystate level of mitochondrial enzymes due to a selective impairment of mitochondrial biogenesis. This may be the primary lesion. The low level of monoamine oxidase (a mitochondrial outer membrane enzyme) may contribute to the neurologic alterations and metabolic perturbations by promoting the synthesis of false neurotransmitters derived from tyramine and by promoting the release of catecholamines from chromaffin tissue.

There is now extensive evidence that hepatic mitochondrial enzyme activity is reduced in Reye's syndrome $(4,6,15,25,26$, $31,32,35)$. It is not yet known how unique these alterations are to Reye's syndrome. To make comparisons between Reye's syndrome and other disease states, it will be necessary to examine not only mitochondrial enzymes, but also enzymes associated with other subcellular compartments because these may provide a means for discriminating between alterations unique to Reye's syndrome and those which may be associated with other disease states. One purpose of this study was to examine a group of enzymes which would contain representative members of various subcellular locations (i.e., soluble cytosolic and endoplasmic reticulum compartments, as well as different intramitochondrial locations). In addition, the group was selected to contain enzymes associated with different metabolic functions as well as enzymes which might be expected to undergo either slow (e.g., lactate dehydrogenase) or rapid (e.g., glucose 6-phosphate dehydrogenase) alterations in their steady-state levels in response to sudden changes in the hormonal or nutritional status of the individual ( 3 , 29).

A second objective of this study was to develop a simple method for measuring mitochondrial dysfunction, with the intention of measuring the extent of mitochondrial impairment in earlier stages of the disease using a portion of the tissue obtained by needle biopsy for diagnostic purposes.

\section{PATIENTS AND METHODS}

\section{PATIENTS}

Liver specimens were obtained from eight children who were admitted to the Children's Hospital of Michigan. Seven patients were diagnosed as Reye's syndrome cases based on typical clinical presentation, together with elevation of serum glutamic-oxaloacetic transaminase and serum glutamic-pyruvic transaminase and characteristic alterations in liver morphology (i.e., panlobular fatty metamorphosis and generalized mitochondrial swelling (24) (Table 1). An eighth case (R-903) was admitted after a documented Brazilian influenza prodromal illness and had elevated transaminase level (serum glutamic-oxaloacetic transaminase, 850 IU/liter; serum glutamic-pyruvic transaminase 620 IU/liter) upon admission. Two spinal fluid measurements showed markedly elevated protein levels ( 150 and $160 \mathrm{mg} \%$ ) with a 10 -fold increase in the myelin protein levels. A brain CATSCAN did not show edema, but was indicative of acute demyelination. Liver biopsy tissue was not characteristic of Reye's syndrome. Mitochondrial changes were minimal and focal in distribution, with no excessive accumulation of fat in the hepatocyte. Data on the hepatic enzyme levels for this patient are included to permit comparison between classical Reye's syndrome and a disease state which resembles the syndrome.

Liver specimens were either obtained after brain death but before disconnection of respiratory support systems, unless otherwise indicated, or by needle biopsy obtained earlier in the course of the disease. In the latter case, one-half of the specimen was used for histologic examination for diagnostic purposes, and the remaining portion was used for a limited number of enzyme studies. Severity of coma was estimated using a modification of the procedure of Lovejoy et al. (21).

\section{CONTROL TISSUE}

Liver specimens were obtained from four children who had died in coma due to cerebrovascular accident (C-2 and C-4), as a result of cardiopulmonary arrest while undergoing elective surgery $(\mathrm{C}-1)$, or during cardiac catheterization performed in connection with a congenital heart defect (C-3). Except for C-3, specimens were obtained before disconnection of the respirator after brain 
Table 1. Clinical features of the Reye's syndrome group

\begin{tabular}{|c|c|c|c|c|c|c|c|}
\hline Patient & Sex & $\begin{array}{l}\text { Age } \\
(\mathrm{yr})\end{array}$ & $\begin{array}{c}\text { SGOT }^{\prime} \\
\text { (IU/liter) }\end{array}$ & $\begin{array}{c}\text { SGPT } \\
\text { (IU/liter) }\end{array}$ & $\begin{array}{l}\text { Prothrombin } \\
\text { time } \\
(\mathrm{sec})\end{array}$ & $\begin{array}{l}\text { Admission } \\
\text { coma } \\
\text { (stage) }\end{array}$ & $\begin{array}{c}\text { Biopsy } \\
\text { (hrs after admission) }\end{array}$ \\
\hline R-705 & $\mathrm{F}$ & 3 & 258 & 123 & $13.2 / 12.2$ & 11 & 44 \\
\hline $\mathrm{R}-802$ & $\mathrm{M}$ & 4.5 & 1310 & 1755 & $15.7 / 10.9$ & V & 120 \\
\hline R-810 & $F$ & 7 & 960 & 1050 & $15.5 / 11.3$ & III & 60 \\
\hline R-811 & $\mathrm{F}$ & 7 & 610 & 1320 & $16.7 / 11.9$ & II & 98 \\
\hline R-901 & $M$ & 13 & 365 & 87 & $18.8 / 12.5$ & IV & 8 \\
\hline R-902 & $\mathrm{M}$ & 9 & 370 & 760 & $15.0 / 11.2$ & II & 5.5 \\
\hline R-903 & $\mathrm{M}$ & $1.5^{2}$ & 850 & 620 & $12.4 / 11.5$ & IV & 71 \\
\hline R-904 & $\mathrm{F}$ & 8.5 & 100 & 330 & $16.0 / 12.5$ & II & 20 \\
\hline
\end{tabular}

${ }^{1}$ SGOT, serum glutamic-oxaloacetic transaminase; SGPT, serum glutamic-pyruvic transaminase.

${ }^{2}$ This patient was admitted with suspected Reye's syndrome (see text). The final diagnosis was demyelenating encephalitis (Brazilian influenza A). This case was included in the study for purposes of comparison.

death. Parental consent was obtained for all of the above procedures.

Specimens were stored in liquid nitrogen or at $-70^{\circ} \mathrm{C}$ until used for enzyme analysis. Separate experiments showed little or no difference in the activities of the enzymes examined in tissue specimens obtained from the same individual before disconnection of the respirator or at autopsy several hrs later. Aging experiments with liver homogenates showed no differences between the lability of enzyme activities in Reye's syndrome and control tissue.

Approximately $90 \%$ of the glutamate dehydrogenase activity (mitochondrial matrix marker) was released into the supernatant fraction, after tissue disruption, performed as described below. The extent of release from Reye's tissue did not differ from that of control. Enzyme activities showed only small changes (up to $10 \%$ ) during storage at $-20^{\circ} \mathrm{C}$, after tissue disruption. Reye's and control samples underwent parallel changes so that the alterations were automatically compensated for when the samples were analyzed later.

\section{BIOCHEMICAL REAGENTS AND ENZYMES}

Reagents and enzymes were obtained from Sigma Chemical Company, St. Louis, MO. Tween 80 (cytochrome oxidase assay) and Triton X-100 (glucose 6-phosphatase assay) were obtained from Sigma Chemical Co. and Eastman Kodak Co., Rochester, NY, respectively.

\section{ENZYME ANALYSIS}

Portions of specimen (typically $20 \mathrm{mg}$ ) were thawed and homogenized in $1 \mathrm{ml}$ of $0.1 \mathrm{M}$ potassium phosphate buffer, $\mathrm{pH} 7.5$, at $0^{\circ} \mathrm{C}$. The homogenate was sonicated $(5-\times 1.5-\mathrm{sec}$ bursts, Branson S 75 Sonifier, with microtip attachment, No. 2 tap) to disrupt the mitochondria and release matrix enzymes. The homogenate was centrifuged at $100,000 \times g$ for $1 \mathrm{hr}$, and the supernatant fraction was used for the assay of non-membranebound enzymes. The pellet was resuspended in $0.5 \mathrm{ml}$ of buffer and used for the assay of cytochrome oxidase, glucose 6-phosphatase, and monoamine oxidase. With needle biopsies, one-half of these amounts of tissue and buffer were used. Tissue from control and Reye's syndrome cases were worked up simultaneously, and the supernatant and pellet fractions were divided into aliquots which were stored at $-20^{\circ} \mathrm{C}$ until the time of assay, usually within 2 wk of preparation.

The activities of control and Reye's samples were measured for a given enzyme on the same day.

\section{ENZYME ASSAYS}

The following enzymes were assayed at $340 \mathrm{~nm}$ using an Aminco DW 2 spectrophotometer in split-beam mode: lactate dehydrogenase (28), glucose 6-phosphatase (23), alanine aminotransferase $(30)$, glutamate dehydrogenase $(9)$, glucose 6-phosphate dehydrogenase (22), and malate dehydrogenase (22). The following activities were measured in the dual wavelength mode because of turbidity and small absorbance changes: cytochrome oxidase $(8,16), 550-540 \mathrm{~nm}$; monoamine oxidase (34), 250 to $310 \mathrm{~nm}$; NADP-linked isocitrate dehydrogenase, $340-550 \mathrm{~nm}$ (assay conditions, Sigma Technical Bulletin No. 153, March, 1977). The glucose 6-phosphatase assay was a two-step process and involved the formation of glucose 6-phosphate from glucose and inorganic pyrophosphate as the first step (23). This procedure is less likely to be affected by the action of nonspecific phosphatases than the measurement of phosphate release in the presence of $\mathrm{Mg}^{2+}$. Protein was determined as described by Beechey $e t$ al. (2). Enzyme activity is expressed in the tables as IU/mg of soluble or particulate protein (depending on the location of enzyme activity), with the exception of cytochrome oxidase activity, which is expressed as the apparent first-order rate constant divided by the amount of particulate protein present in the assay mixture.

\section{ELECTROPHORETIC MEASUREMENTS OF MALATE DEHYDROGENASE ACTIVITIES}

Mitochondrial and cytosolic forms of the enzyme were separated on polyacrylamide gels by a procedure similar to that for lactate dehydrogenase isozymes (7) except that the upper chamber buffer was adjusted to $\mathrm{pH} 8.65$ to improve migration of the slow band into the gel. Malate dehydrogenase activity was visualized by staining essentially as described by Brewer (5). Band intensities were measured with a Beckman densitometer, and the relative enzyme activities were calculated ffrom the areas under the curves. Identification of the slow and fast bands as mitochondrial and cytosolic enzymes, respectively, was made using marker enzyme activity obtained from fractionated, unfrozen, human liver.

Statistical analysis of differences between group means was performed using Student's $t$ test (33).

\section{RESULTS}

The activities of nine enzymes in liver specimens obtained from four children who had died from Reye's syndrome were compared to the corresponding activities of a control group of four children who had died from unrelated causes (Table 2). At the $95 \%$ significance level, the alterations could be classified into three groups. Five activities [lactate dehydrogenase, alanine aminotransferase, glucose 6-phosphatase, cytochrome oxidase, and malate dehydrogenase (mitochondrial plus cytosolic)] showed no change. Three enzymes [glutamate dehydrogenase, isocitate dehydrogenase (NADP), and monoamine oxidase] were decreased. One activity (glucose 6-phosphate dehydrogenase) was increased.

The lowered activity of monoamine oxidase in Reye's syndrome (Table 2) means that the mitochondrial abnormalities extend to the outer mitochondrial membrane. The decrease in membranebound monoamine oxidase activity was not accompanied by the appearance of a soluble form of the oxidase.

The difference in activity of giutamate dehydrogenase between Reye's and control liver tissue did not appear to be due to the presence of an allosteric inhibitor in the Reye's sample or an activator in the control sample. This conclusion is based on the observation that mixtures of supernatant fractions of Reye's and 
Table 2. Liver enzyme activities in terminal specimens of liver from Reye's syndrome and control cases ${ }^{1}$

\begin{tabular}{|c|c|c|c|c|}
\hline \multirow[b]{2}{*}{ Enzyme } & \multicolumn{4}{|c|}{ Means } \\
\hline & Reye's syndrome & \multicolumn{2}{|r|}{ Control } & \multirow{2}{*}{$\frac{P<}{0.9}$} \\
\hline $\begin{array}{l}\text { Lactate dehydro- } \\
\text { genase }^{2}\end{array}$ & $1.01 \pm 0.165^{3}$ & 1.00 & \pm 0.158 & \\
\hline $\begin{array}{l}\text { Malate dehydro- } \\
\text { genase }^{2,4}\end{array}$ & $0.132 \pm 0.0124$ & 0.117 & \pm 0.014 & 0.1 \\
\hline $\begin{array}{l}\text { Glutamate dehy- } \\
\text { drogenase }^{4}\end{array}$ & $0.048 \pm 0.0078$ & 0.120 & \pm 0.0078 & 0.001 \\
\hline $\begin{array}{l}\text { Alanine amino- } \\
\text { transferase } \\
2.4\end{array}$ & $0.086 \pm 0.0171$ & 0.091 & \pm 0.0053 & 0.5 \\
\hline $\begin{array}{l}\text { Isocitrate dehydro- } \\
\text { genase }^{2,4}\end{array}$ & $0.158 \pm 0.0087$ & 0.188 & \pm 0.0204 & 0.02 \\
\hline $\begin{array}{l}\text { Glucose 6-phos- } \\
\text { phatase }^{5}\end{array}$ & $0.028 \pm 0.0176$ & 0.037 & \pm 0.0102 & 0.4 \\
\hline $\begin{array}{l}\text { Glucose 6-phos- } \\
\text { phate dehydro- } \\
\text { genase }^{2}\end{array}$ & $0.0076 \pm 0.00157$ & 0.0055 & \pm 0.00055 & 0.02 \\
\hline $\begin{array}{l}\text { Monoamine oxi- } \\
\text { dase }^{6}\end{array}$ & $0.0009 \pm 0.00033$ & 0.00255 & \pm 0.000207 & 0.001 \\
\hline $\begin{array}{l}\text { Cytochrome oxi- } \\
\text { dase }^{i}\end{array}$ & \pm 0.31 & 1.02 & \pm 0.295 & 0.1 \\
\hline \multicolumn{5}{|c|}{$\begin{array}{l}\text { 'Enzyme activities are expressed as enzyme activity in } 1 \mathrm{U} \text { (except for } \\
\text { cytochrome oxidase) per mg of soluble protein (for supernatant fraction } \\
\text { enzymes) or per mg of particulate protein (for the protein pellet fraction) } \\
\text { Cytochrome oxidase activities are expressed as the first order rate constant } \\
\text { for the oxidation of reduced cytochrome } c \text { (observed), divided by the mg } \\
\text { of particulate protein. } \\
{ }^{2} \text { Cytosol. } \\
{ }^{3} \text { Mean } \pm \text { S.D. are obtained from four cases of Reye's syndrome and }\end{array}$} \\
\hline
\end{tabular}

control samples had enzyme activities which were the sum of the individual activities measured separately. A diffusible inhibitor would be expected to produce lower than predicted activity in these mixtures and an activator to produce greater than predicted activity.

The malate dehydrogenase activity measured spectrophotometrically was the sum of both the mitochondrial and the cytosolic enzyme activity. To investigate the changes in the cytosolic relative to the mitochondrial form, the malate dehydrogenases were separated electrophoretically on polyacrylamide gels, and the two bands were stained and measured using a densitometer. The relative amounts of each enzyme (expressed in arbitrary units) was obtained from the areas under the curves. The ratio of cytosolic:mitochondrial malate dehydrogenase was significantly greater for Reye's syndrome than for control liver specimens (Table 3 ). This is again compatible with the view that there is a general decrease in mitochondrial relative to cytosolic activity in Reye's syndrome.

NADP-linked isocitrate dehydrogenase activity is associated with both the cytosolic and the mitochondrial matrix compartments. The decrease in total activity shown in Table 2 suggests that in human liver, the mitochondrial activity may be predominant. This point requires further investigation. The NAD-linked enzyme was also measured in the presence of ADP, an allosteric activator. The NAD-linked activity was only about $1 / 10$ that of the NAD-linked dehydrogenase. Preliminary experiments showed that the NAD-linked enzyme was not significantly different when the Reye's was compared to the control sample.

Table 3 also shows the cytosolic:mitochondrial relationship as judged by the lactate dehydrogenase:glutamate dehydrogenase ratio. From these studies, it was concluded that either the foregoing
Table 3. Alterations in the ratios of cytosolic to mitochondrial enzyme activities in liver samples obtained from stage $V$ Reye's syndrome patients

\begin{tabular}{|c|c|c|c|c|}
\hline \multirow[b]{2}{*}{ Patients } & \multirow[b]{2}{*}{ Sex } & \multirow[b]{2}{*}{ Age } & \multirow[b]{2}{*}{$\begin{array}{c}\text { Lactate deHase } \\
\text { Glutamate deHase }\end{array}$} & \multirow{2}{*}{ 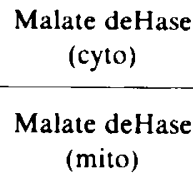 } \\
\hline & & & & \\
\hline \multicolumn{5}{|c|}{ Reye's syndrome } \\
\hline R-705 & $\mathrm{F}$ & $3 y$ & 25.08 & 1.320 \\
\hline R-802 & $\mathbf{M}$ & $4.5 y$ & 17.21 & 1.033 \\
\hline R-810 & $\mathrm{F}$ & $7 y$ & 25.09 & 1.174 \\
\hline R-811 & F & $7 y$ & 18.56 & 1.304 \\
\hline Mean & & & $21^{1}$ & $1.2^{2}$ \\
\hline S.D. & & & 4.2 & 0.13 \\
\hline \multicolumn{5}{|l|}{ Control } \\
\hline$C-1$ & $\mathbf{M}$ & $10 y$ & 7.65 & 0.852 \\
\hline C-2 & $\mathbf{M}$ & $13 y$ & 7.59 & 0.786 \\
\hline C-3 & $\mathrm{F}$ & $13 \mathrm{~m}$ & 10.68 & 0.852 \\
\hline$C-4$ & $\mathbf{M}$ & $8 y$ & 7.76 & 0.587 \\
\hline Mean & & & $8^{\prime}$ & $0.8^{2}$ \\
\hline S.D. & & & 1.5 & 0.13 \\
\hline
\end{tabular}

${ }^{1}$ These values are significantly different $(P<0.01)$.

${ }^{2}$ These values are significantly different $(P<0.01)$.

Table 4. Ratios of cytosolic to mitochondrial enzyme activies in liver specimens obtained by needle biopsy at various stages of coma

\begin{tabular}{|c|c|c|c|c|}
\hline & & & & $\begin{array}{l}\text { Malate deHase } \\
\text { (cyto) }\end{array}$ \\
\hline Patient & Stage' & $\begin{array}{l}\text { Out } \\
\text { come }\end{array}$ & $\frac{\text { Lactate deHase }}{\text { Glutamate deHase }}$ & $\begin{array}{l}\text { Malate deHase } \\
\text { (mito) }\end{array}$ \\
\hline
\end{tabular}

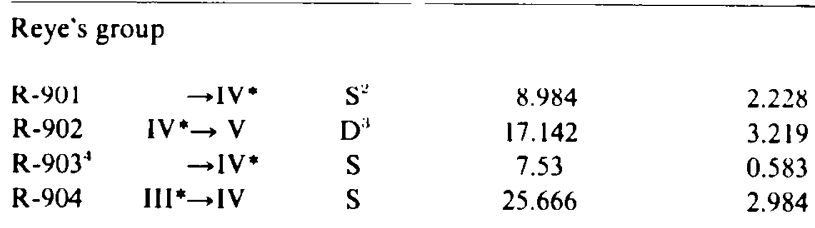

Control group

\begin{tabular}{lll} 
C-2 & 7.108 & 0.764 \\
C-3 & 9.268 & 0.567 \\
\hline
\end{tabular}

$1 *$, stage at time of biopsy; arrow, most severe stage reached.

${ }^{2} S$, survived; $D$, died

${ }^{3}$ An additional specimen was obtained at stage $\mathrm{V}$ before disconnecting the respiratory support systems. The ratios for lactate dehydrogenase: glutamate dehydrogenase and cytosolic:mitochondrial malate dehydrogenase activities were 20.46 and 1.575 , respectively.

${ }^{4}$ This case was admitted with a provisional diagnosis of Reye's syndrome. (See text and Table 1).

ratio or the malate dehydrogenase ratios offered a quantitative basis for describing the extent of mitochondrial dysfunction.

The foregoing studies clearly showed that imbalances of cytosolic:mitochondrial activities could be detected in liver specimens from stage $\mathrm{V}$ patients. These methods were therefore applied to study needle biopsy specimens obtained earlier in the course of the disease with the intention of measuring the extent of mitochondrial dysfunction under conditions where the neurologic abnormalities were less severe. Results are summarized in Table 4 , which also shows values for two control group samples used as an internal standard. Two patients had elevated ratios of both glutamate:lactate dehydrogenase and cytosolic:mitochondrial malate dehydrogenase (R-902 and R-904). The former continued to 
stage $\mathrm{V}$ with little improvement of the cytosolic:mitochondrial imbalance. The latter continued to stage IV, but subsequently recovered. One patient (R-901) appeared to have a normal level of glutamate dehydrogenase, but an abnormal malate dehydrogenase ratio. This may be an experimental artifact, or it may represent time-dependent enzyme changes in the disease. Patient $\mathrm{R}-903$ showed no abnormality in either ratio in stage IV coma. The enzyme studies thus do not support a classical Reye's syndrome case. Electron microscopic analysis of liver biopsy material also failed to show the characteristic features of Reye's syndrome. Focal, mild disconfiguration of mitochondria was seen, but there was no accumulation of fat droplets in the hepatocyte or evidence of generalized mitochondrial swelling (Fig. 1). In contrast, a biopsy specimen taken from another patient (R-901) at the same stage of coma showed characteristic alterations (Fig. 2).

\section{DISCUSSION}

The results presented here are in agreement with the work of others cited previously and show that the decreases in enzyme activity in liver in Reye's syndrome patients appear to be confined to mitochondrial enzymes. This survey differs from that of Robinson et al. (26) insofar as it presents data for a wider range of nonmitochondrial enzymes. In no case was a nonmitochondrial enzyme found to be decreased. In one case (glucose 6-phosphate dehydrogenase), an activity was found to be slightly increased.

The intracellular concentration of glucose 6-phosphate dehydrogenase is known to vary with nutritional status, i.e., the enzyme level exerts a regulatory function (37). The slight elevation noted here may be in response to glucose administration, or it may reflect part of the pathology, with a funnelling of reducing equivalents away from mitochondrial oxidative metabolism toward lipid biosynthesis. This type of process has been proposed to occur in infarcted heart tissue, where oxidative metabolism is impaired
(18). An increased activity of a cytosolic enzyme in Reye's syndrome implies that there is not a general lesion affecting protein synthesis or its regulation by the hepatocyte.

Nevertheless, it is possible that there is a decrease in the rate of synthesis of secretory and certain membrane-bound proteins. These proteins are synthesized on the rough endoplasmic reticulum. The proliferation of smooth endoplasmic reticulum in Reye's syndrome hepatocytes (24) (see Fig. 2) could be the result of either de novo synthesis of smooth membrane or the loss of ribosomes from rough endoplasmic reticulum. Glucose 6-phosphatase is known to be uniformly distributed in activity throughout the rough and smooth endoplasmic reticulum (38). Thus, the observation that this enzyme is not increased in the particulate fraction of liver tissue (Table 2) suggests that the smooth membrane was derived from the rough, rather than by net synthesis of smooth endoplasmic reticulum. An impairment of protein synthesis does not mean that all affected proteins show a similar decrease in activity at a given time. It is the rate of protein degradation rather than that of synthesis which governs the approach to a new steady-state level $(3,29)$.

The decrease in activity of monoamine oxidase, a marker enzyme for the outer mitochondrial membrane (17) shows that the mitochondrial changes are not confined to matrix or inner membrane locations. The pharmacologic implications of this observation have yet to be explored. Liver monoamine oxidase may serve to keep the levels of tyramine and octopamine low (11), and it has been reported that severe hepatic dysfunction correlates well with elevated levels of octopamine in the hypothalamic region of brain, both in Reye's and non-Reye's encephalopathies (20). The elevated levels of monoamine metabolites in ventricular fluids in Reye's syndrome patients would point to an increased rate of monoamine metabolism by brain (27) at a time when the liver monoamine oxidase function appears to be impaired. In Reye's syndrome, plasma tyramine levels correlate well with number of

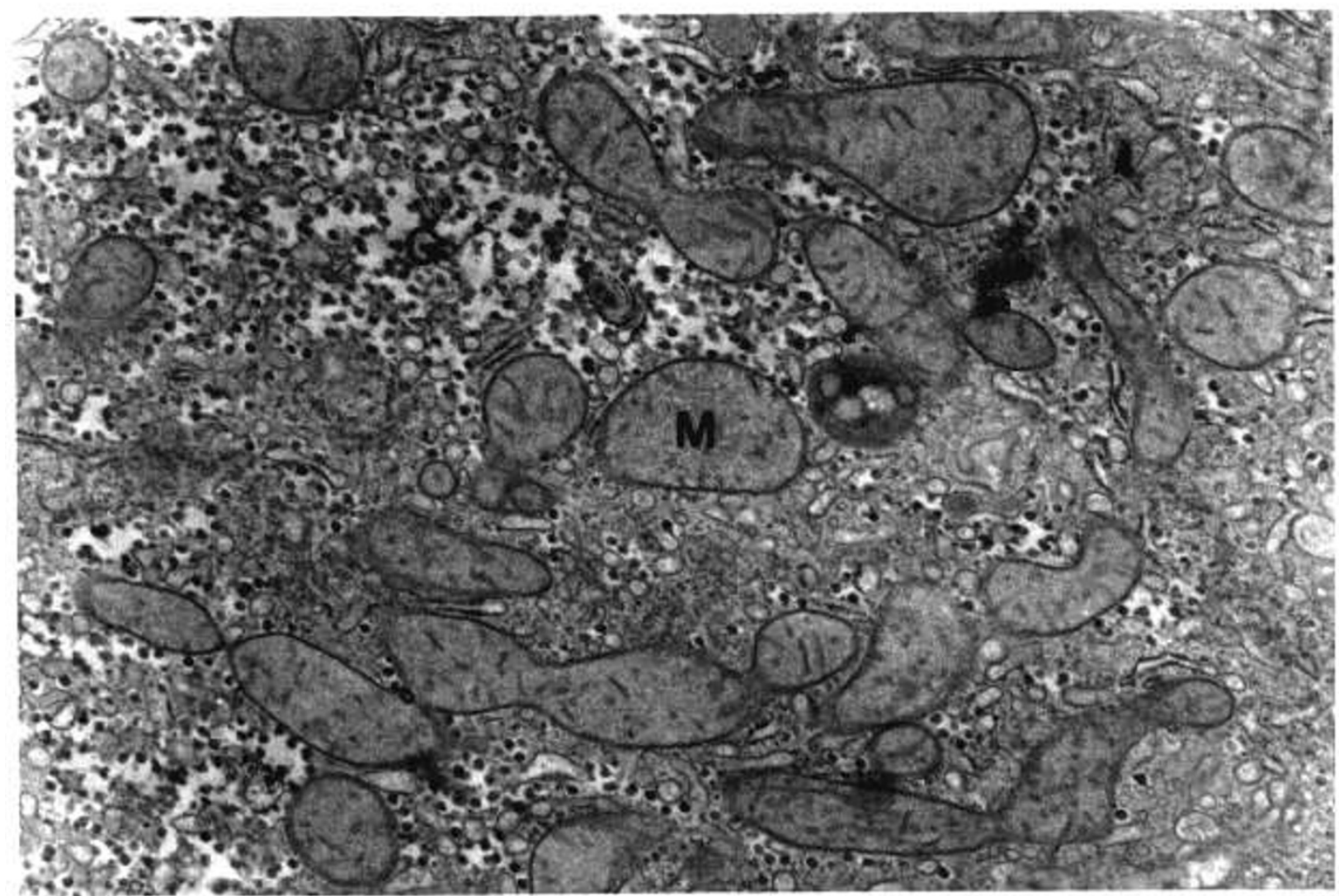

Fig. 1. Electron micrograph of liver specimen R-903 $(\times 18700)$. Although in this selected area there is considerable disconfiguration of the external contour of the mitochondria $(M)$, the matrix and inner and outer membrane appear normal. Glycogen $(G)$ storage is fairly abundant and fat droplets are rare. 


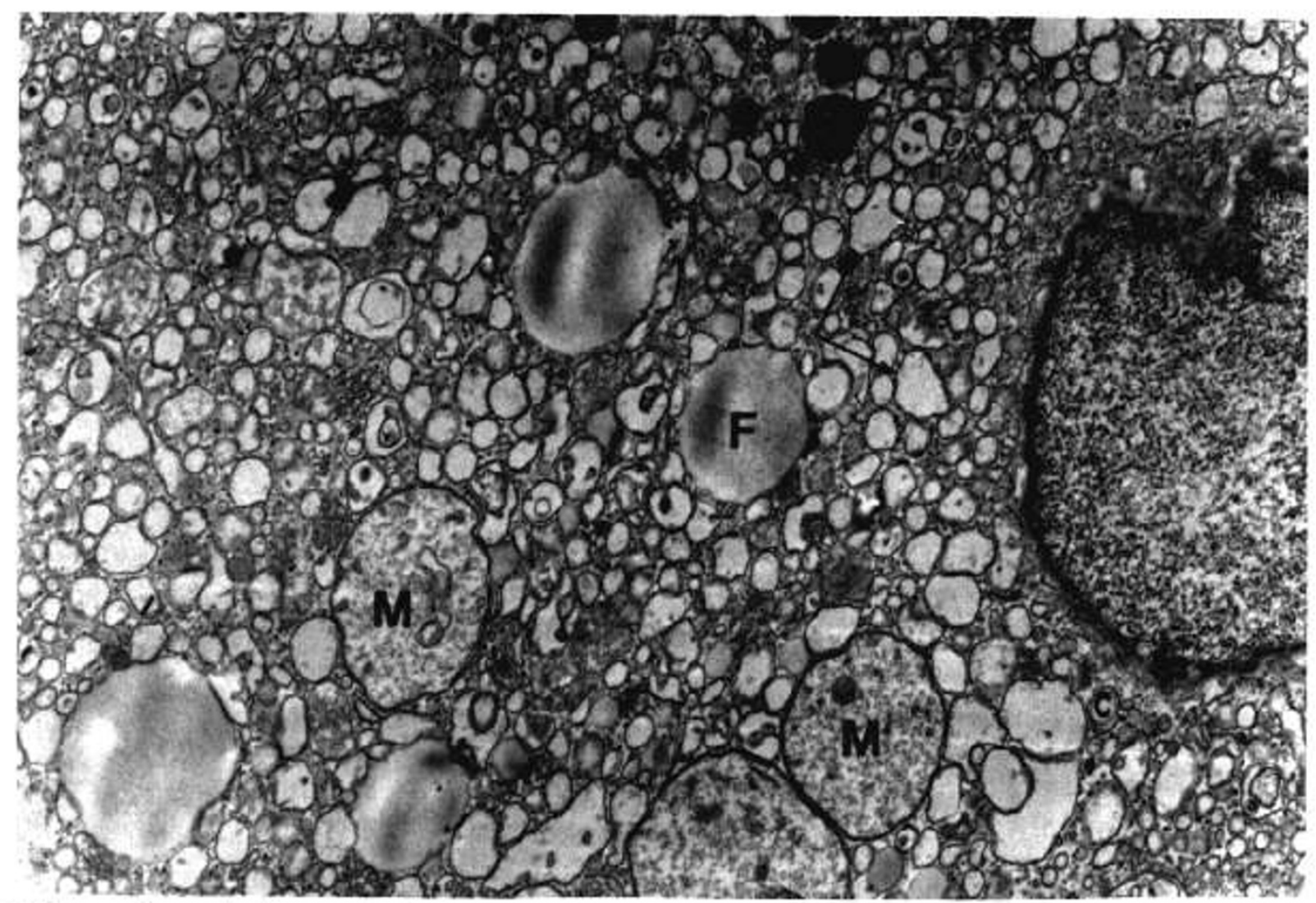

Fig. 2. Eiectron micrograph of liver specimen R-901 showing a classical picture of Reye's syndrome $(\times 15400)$. There is generalized marked swelling of mitochondria $(M)$ with rarefaction of matrix. Also observed are many small fat droplets $(F)$, decoated endoplasmic reticulum $($ arrow $)$ and depletion of glycogen.

days in coma (10). Tyramine-induced hypercatecholemia may contribute to neurologic or renal impairment in later stages of the disease.

A general feature of Reye's syndrome appears to be a decrease in the steady-state level of many mitochondrial enzymes. Mitochondrial proteins turn over at different rates, so it would not be surprising to find that the extent of enzyme depletion differed from enzyme to enzyme. This may account for the failure to observe marked depletion of cytochrome oxidase and NAD-linked isocitrate dehydrogenase. Histologic evidence also points to the possibility that cytochrome oxidase may be only slightly impaired at a time when succinate dehydrogenase is diminished (4). Such differential changes could result from impairment of mitochondrial biogenesis.

Regardless of the actual cause of mitochondrial dysfunction, the extent of the lesion readily can be estimated by measuring either the lactate:glutamate dehydrogenase or the cytosolic:mitochondrial malate dehydrogenase ratio. These procedures are suitable for examination of small portions of needle biopsy material obtained primarily for diagnostic purposes. The ratios provide a convenient means for quantitatively expressing the extent of mitochondrial dysfunction in early stages of the disease. Early failure of normal mitochondrial liver function would be expected to give rise to characteristic alterations in blood metabolites. A correlation between the extent of liver mitochondrial failure (as judged by the enzyme pattern in needle biopsy tissue) and the elevation of metabolites such as tyramine and perhaps lactate (arising from diminished monoamine oxidase and pyruvate dehydrogenase activities, respectively) might lead to improved methods of diagnosis not requiring liver biopsy. Such a correlation might also lead to better information about the extent of liver malfunction before more severe neurologic complications ensued. Histologic examination of liver (4) showed striking decreases in succinate dehydrogenase activity soon after onset of encephalopathy. However, even when the encephalopathy was mild, prominent decreases were still observed in two of three cases examined. These results suggest that there may be variations in the extent of liver mitochondrial dysfunction in Reye's syndrome in the early stages of Reye's syndrome, when the neurologic aberrations are not prominent.

This type of information may help to distinguish between Reye's syndrome and other neurologic disease states which resemble it, but which either do not show evidence for the early involvement of liver (1) or are in some other way atypical $(12-14,19,36)$.

\section{REFERENCES AND NOTES}

1. Applebaum, M. M.. and Thaler, M. M.: Reye's syndrome without initial hepatic involvement. Am. J. Dis Child, 131.295 (1977).

2. Beechey, R. B., Hubbard, S. A., Linnnett. P. E., Mitchell, A. D., and Munn, E. A.: A simple and rapid method for the preparation of adenosine triphosphatase from submitochondrial particles. Biochem. J., 148: 533 (1975).

3. Berlin. C. M., and Schimke. R. T.: Influence of turnover rates on the responses of enzymes to cortisone. Mol. Pharmacol., I: 149 (1965).

4. Bove, K. E., McAdams, A. J., Partin, J. C., Partin, J. S., Hug, G., and Schubert W. K.: The hepatic lesion in Reye's sydrome. Gastroenterology, 69: 685 (1975).

5. Brewer, G. J.: In: Introduction to isozyme techniques. pp. 47-5I (Academic Press, Inc., New York, 1970).

6. Brown, T., Hug, G., Lansky, L.. Bove, K., Shere, A., Ryan, M., Brown, H., Schubert. W. K., Partin, J. C.. and Lloyd-Still, J.: Transiently reduced activity of carbamyl phosphate synthetase and ornithine transcarbamylase in liver of children with Reye's syndrome. N. Engl. J. Med., 294: 861 (1976).

7. Cooper, T. G.: The tools of biochemistry. (Wiley-Interscience. New York. 1977).

8. Cooperstein, S. J., and Lazarow, A.: A microspectrometric method for the determination of cytochrome oxidase. J. Biol. Chem., 189: 665 (1951).

9. Fahien, L. A., and Cohen, P. P.: L-Glutamate dehydrogenase (frog and tadpole liver). Methods Enzymol., 17A: 839 (1970).

10. Faraj, B. A., Newman, S. L., Caplan, D. B., Farouk, M. A., Camp, V. M., and Ahman. P. A.: Evidence for hypertyraminemia in Reye's syndrome. Pediatrics. 64: 76 (1979).

11. Fischer, J. E., and Baldessarini, R. J.: False neurotransmitters and hepatic failure. Lancet. 2: 75 (1971)

12. Gall. D. B., Cutz, E. McLung, H. J., and Greenberg, M. L.: Acute liver disease and encephalopathy mimicking Reye's syndrome. A report of three cases. J. Pediatr., 87: 869 (1975). 
13. Glasgow, A. M., Cotton, R. B., Bourgeois, C. H., and Dhiensiri, K.: Reye's syndrome II. Occurrence in the absence of severe fatty infiltration of the liver. Am. J. Dis. Child., 124: 836 (1972).

14. Gosseye, S., DeMeyer, R., and Maldague, P.: Reye's syndrome without fatty liver. Helv. Paediatr. Acta. 30: 509 (1976)

15. Greene, H. L., Wilson. F. A.. Gluck. A. D., Dunn. G. D., and Kilroy, A. W. Hepatic ATP concentrations and glycolytic enzyme activities in Reye's syndrome. J. Pediatr., 89: 777 (1976).

16. Greenwald, C., Brittain. T.. Wilson, M., and Brunori, M.: Studies on partially reduced mammalian cytochrome oxidase reactions with ferrocytochrome $c$. Biochem. J., 157: 591 (1976).

17. Greenwalt, J. W., and Schnaitman, C.: An appraisal of the use of monoamine oxidase as an enzyme marker for the outer membrane of rat liver mitochondria. J. Cell. Biol., 46: 173 (1970)

18. Gudbjarnason, S., Braasch. W., Cowan, C., and Bing, R. J.: Metabolism of infarcted heart muscle during tissue repair. Am. J. Cardiol., 22: 360 (1968).

19. Krieger, I., Snodgrass. P. J., and Roskamp. J.: Atypical clinical course of OTCase deficiency due to a new mutant (comparison with Reye's disease). J. Clin. Endocrinol. Metab., 48: 388 (1979).

20. Lloyd, K. G., Davidson, L., Price, K., McClung, H. J., and Gall, D. G.: Catecholamine and octopamine concentrations in brains of patients with Reye's syndrome. Neurology, 27: 985 (1977).

21. Lovejoy, F. H., Smith, A. L., Bresnan, M. J., Wood, J. N., Victor, D. I., and Adams, P. C.: Clinical staging in Reye's syndrome. Am. J. Dis. Child., 128: 36 (1974).

22. Lowry, O. H., and Passoneau, J. V.: A flexible system of enzymatic analysis. pp. 179-182, 201-204 (Academic Press, Inc., New York, 1972).

23. Nordlie, R. C., and Arion, W. J.: Glucose-6-phosphatase. Methods Enzymol., 9: 619 (1966).

24. Partin, J. C., Schubert, W. K., and Partin, J. S.: Mitochondrial ultrastructure in Reye's syndrome (encephalopathy and fatty degeneration of viscera). N. Engl. J. Med., 285: 1339 (1971).

25. Robinson, B. H., Gall. D. G., and Cutz, E.: Deficient activity of hepatic pyruvate dehydrogenase and pyruvate carboxylase in Reye's syndrome. Pediatr. Res., 11: 279 (1977).

26. Robinson. B. H., Taylor, J., Cutz, E., and Gall, D. G.: Reye's syndrome preservation of mitochondrial enzymes in brain and muscle compared with liver. Pediatr. Res., 12: 1045 (1978)

27. Schaywitz. B. A., Venes, J., Cohen, D. J., and Bowers, M. B.: Reye's syndrome monoamine metabolites in ventricular fluid. Neurology, 29: 467 (1979).

Copyright (1) 1980 International Pediatric Research Foundation, Inc

$0031-3998 / 80 / 1411-1216 \$ 02.00 / 0$
28. Schwartz, M. K., and Bodansky, O.: Lactate dehydrogenase (clinical aspects) Methods Enzymol., 9: 294 (1960)

29. Segal, H. L., Kim, Y. S., and Hopper, S.: Glucocorticoid control of rat liver glutamic-alanine transaminase biosynthesis. Adv. Enzyme Regul., 3: 29 (1965)

30. Segal, H. L., and Matsuzawa. T.: L-Alanine aminotransferase (rat liver). Methods Enzymol., 17: $153(1970)$

31. Sinatra. F., Yoshida. T.. Applebaum, M.. Mason, W.. Hoogenraad, N. J. and Sunshine, P.: Abnormalities of carbamyl phosphate synthetase and ornithine trranscarbamylase in liver of patients with Reye's syndrome. Pediatr. Res., 9. 829 (1975).

32. Snodgrass, P. J., and DeLong, G.: Urea cycle deficiencies and an increased nitrogen load producing hyperammonemia in Reye's syndrome. N. Engl. J. Med., 294: 855 (1976)

33. Sokahl, R. R., and Rolfe. F. J.: In: Biometry. pp. 143-145 (W. H. Freeman and Co., San Francisco, CA 1969).

34. Tabor, C. W., Tabor, H., and Rosenthal, S. M.: Amine oxidases (A) amine oxidase from steer plasma. Methods Enzymol., 2: 390 (1955).

35. Thaler, M. M., Hoogenraad, N. J., and Boswell, M.: Reye's syndrome due to a novel protein tolerant variant of ornithine-transcarbamylase deficiency. Lancet. 2: 438 (1974).

36. Washington. R. L., Barkin, R. M., and Hillman, J. R.: Septicemia plague that mimics Reye's syndrome. Am. J. Dis. Child., 133: 434 (1979).

37. Winberry, L., and Holten, D.: Rat liver glucose 6-phosphate dehydrogenase dietary regulation of the rate of synthesis. J. Biol. Chem., 252: 7796 (1977).

38. Winquist, L., and Dallner, G.: Localization of enzymes in specialized regions of the microsomal membrane. Biochim. Biophys. Acta, 436: 399 (1976).

39. The authors express their appreciation to Sanford N. Cohen, M.D., Felix R. Fernandez-Madrid. M.D. Bennie Zak. Ph.D., and Franklin E. Hull. M.D., for their assistance in this project.

40. Requests for reprints should be addressed to: Robert A. Mitchell, Department of Biochemistry. Wayne State University School of Medicine, 550 E. Canfield Avenue, Detroit, Michigan 48201 (USA).

41. This research was supported by the Reye's Syndrome Study Center, Children's Hospital of Michigan, through funds provided by the Kenny-Michigan Rehabilitation Foundation, Michigan Jaycees, Reye Syndrome Association, Skillman Foundation. First Society of Detroit, and Reye Syndrome Memorial Funds.

42. Received for publication September 12, 1979.

43. Accepted for publication March 3, 1980 